\title{
European expert network on rare communicable diseases and other rare diseases linked to mobility and globalisation focused on health care provision (EURaDMoG): a feasibility study
}

Ana Requena-Méndez ${ }^{1,2^{*}}$ D , Zeno Bisoffi ${ }^{3,4}$, Joan-Lluis Vives-Corrons ${ }^{5}$, Joaquim Gascon ${ }^{1}$ and Antoni Plasència ${ }^{1}$

\begin{abstract}
Introduction: In the current mobility and globalization context, there is a growing need to identify potential changes on the pattern of diseases in the European Union (EU)/European Economic Area (EEA) and provide accurate diagnosis and treatment for the population. The pattern of rare communicable diseases that can affect people returning to EU/EEA from travel abroad, visiting EU/EEA or establishing in the EU/EEA is of special relevance. The objective of this manuscript is to give an overview about the EURaDMoG study and discuss the feasibility of establishing a European network on rare communicable diseases and other rare conditions linked to mobility and globalization.

Methods: We undertook a three-steps process where we first conducted a narrative review to estimate the prevalence and incidence and to list rare communicable and non-communicable diseases linked to mobility and globalization in the EU/EEA; second, we organized an international consultation workshop with experts in the diseases previously selected; and finally, the feasibility study analysed how successful a European expert network on rare diseases linked to mobility and globalization focused on health care provision would be, accounting for different operational and also sustainability criteria.

(Continued on next page)
\end{abstract}

\footnotetext{
* Correspondence: ana.requena@isglobal.org

'Barcelona Institute for Global Health (Hospital Clínic- Universitat de Barcelona), Barcelona, Spain

${ }^{2}$ Department of Medicine, Karolinska Institutet, Solna, 17176 Stockholm, Sweden

Full list of author information is available at the end of the article
}

(c) The Author(s). 2020 Open Access This article is licensed under a Creative Commons Attribution 4.0 International License, which permits use, sharing, adaptation, distribution and reproduction in any medium or format, as long as you give appropriate credit to the original author(s) and the source, provide a link to the Creative Commons licence, and indicate if changes were made. The images or other third party material in this article are included in the article's Creative Commons licence, unless indicated otherwise in a credit line to the material. If material is not included in the article's Creative Commons licence and your intended use is not permitted by statutory regulation or exceeds the permitted use, you will need to obtain permission directly from the copyright holder. To view a copy of this licence, visit http://creativecommons.org/licenses/by/4.0/ The Creative Commons Public Domain Dedication waiver (http://creativecommons.org/publicdomain/zero/1.0/) applies to the data made available in this article, unless otherwise stated in a credit line to the data. 
(Continued from previous page)

Results: First, considering the areas or topics that the network should cover, it was concluded that communicable and non-communicable rare diseases linked to mobility and globalization should be differentiated. Second, since all non-communicable rare diseases linked to mobility and globalization identified are already covered by different European Reference Networks (ERNs), there is no need for them to be included in a new European network. Three scenarios were considered for establishing a potential European network for rare communicable diseases linked to Mobility and Globalisation with a focus on Health Care provision: 1) To maintain the current situation "Status Quo" scenario; 2) to create a specific European expert network (EEN) on rare communicable diseases linked to mobility and globalisation; 3) to develop a new ERN on communicable rare diseases linked to mobility and globalisation.

Conclusions: Since the focus is the provision of health care, an ERN could have the potential to better boost the quality of care being facilitated by technological tools and online platforms that permit the safe and ethically acceptable exchange of data. However, this potential new network should not eclipse current existing networks and they should be complementary.

Keywords: Rare diseases, Mobility, Globalisation, Imported diseases, Communicable diseases, Rare infections

\section{Background}

Population movements have had a major impact on disease epidemiology and public health [1]. There is a growing need to provide health care for "rare" diseases that are related to this context. The European Union (EU) /European Economic Area (EEA) countries are tackling new emerging diseases not endemic in EU countries [2] which are not considered rare diseases at the world-wide level, but which are rare conditions in Europe according to the definition of rare diseases from the European Commission (EC) [3] or are emerging due to climate change.

Such a definition of rare diseases was adopted by the Community Action Programme on rare diseases 19992003 as those life-threatening or chronically debilitating diseases presenting a prevalence less than 5 per 10,000 people in the EU [4].

In addition to the limited number of patients, rare diseases are characterised by by scarce knowledge and expertise, single them out as a distinctive domain of very high European added value [5]. European cooperation can help to ensure that scarce knowledge can be shared and resources combined as efficiently as possible, in order to tackle rare diseases effectively across the EU/ EEA as a whole [4]. Classically, most rare diseases are genetic disorders, that is, non-infectious inherited conditions [6], but there are also other rare diseases like rare cancers, auto-immune diseases, toxic disorders and communicable diseases. Imported diseases which are not familiar to European health professionals, have recently been recognized as a new challenge as they have been found to be prevalent only in mobile populations coming from tropical countries [7]. Although most migrants and newly arriving refugees do not pose a special challenge for the autochthonous population in terms of communicable diseases risk [8], they are disproportionately affected by infectious diseases that at some point may have an impact on the health system (critical care for immunosuppressed migrant patients, transplant programs ...) [9]. Therefore, the risk of communicable diseases (CD) is in accordance to the country of origin and/ or transit of migrants and refugees because prevalence rates and burden of CD differ considerably by country [10]. In this regard, additional work is needed to improve the knowledge gaps among different categories of health professionals [9].

In the same way, the increase of global mobility related to tourism or trade has increased the risks of rare communicable diseases in travellers, particularly vector borne diseases [11]. During the last century, invasive mosquito species have become widely established across Europe [12]. Although subsequent transmission and outbreaks of unfamiliar diseases such as Chikungunya and Dengue are in part due to increased globalisation, with intercontinental air travel and global shipping transport [11], changes in vector distributions are also being driven by climatic changes and changes in land use, infrastructure, and the environment [13].

Regarding rare CD, health professionals often lack the necessary skills to correctly identify and treat unfamiliar pathologies, due to their low prevalence in the countries where they are working or because they are newly emerging diseases [14]. In the same way, the increase in global mobility for tourism or trade poses similar risks of rare diseases in travellers, often implying a particular challenge for diagnosis and management [11]. It is also worth mentioning the effect of climate change on vector borne diseases [15]. Sharing medical knowledge and expertise is an important strategy for developing the competencies and skills of health professionals to address patients' needs and support change in health service provision [16, 17]. It is clear that the focus here is the diagnosis and treatment, not the epidemiological surveillance of the diseases. 
On the other hand, non-communicable diseases (NCD) may also represent a challenge in mobile populations, particularly in migrants. Haemoglobin disorders such as thalassemia or sickle cell disease (SCD) are inherited disorders whose frequency varies by ethnic group [18]. Due to population movements, the sickle cell trait has been spread to other places such as the Middle East and Southern Europe [19], where thalassemia has also been endemic until now, also due to the historical endemic presence of malaria until recently. Most rare non communicable diseases are already covered by the existing ERN [20].

The objective of this study was to evaluate the feasibility of a European expert network on rare diseases linked to mobility and globalization focused on Health Care provision.

\section{The EURaDMoG feasibility study}

This study analysed how successfully a European expert network on rare diseases linked to mobility and globalization focused on Health Care provision would be, accounting for different factors or criteria that will be outlined. Through this study, potential positive and negative outcomes of the network have been envisaged. All these factors have been separately assessed considering different scenarios and have been evaluated based on the results of a consultation workshop, with a combined three-step approach: [1] conducting a comprehensive review, a [2] consultation workshop, [3] an overall feasibility assessment. The main results are described hereunder.

1. A comprehensive review was carried out to assess epidemiological, diagnostic and treatment aspects of rare diseases (both communicable and noncommunicable) linked to Mobility and Globalisation and to elaborate a list of rare diseases linked to mobility and globalisation.

The primary objective was to assess which rare diseases (according to the EC definition of rare disease) should be covered by a potential expert European network of rare disease linked to mobility and Globalisation, to review their prevalence and/or incidence in EU/ EEA countries as well as their epidemiological profile.

For that purpose, first a narrative review of the literature has been conducted to explore which rare diseases (both communicable and non-communicable) in EU/ EEA countries are linked to mobility and Globalization. For communicable diseases, first, we reviewed the Orphanet list if rare disease [21], selecting those that are associated with mobility and globalisation. This relationship was established either because these diseases are more frequent in mobile populations (migrants and travellers) irrespective of whether they are imported diseases or not, or because of the risk of being introduced /reintroduced or of changing their epidemiology in EU/EEA countries due to environmental factors such as climate change. We also conducted an online survey with experts in $\mathrm{CD}$ to agree the preliminary of $\mathrm{CD}$ identified. The survey was distributed among European network targeting most of the diseases identified in the list The European Network for Tropical Medicine and Travel Health (TROPNET) [22], the European Travel and Tropical Medicine Network (EUROTRAVNET) [23] and the European Expert laboratory network for emerging viral diseases (EVDLABNET) [24].

Thereafter, the prevalence /incidence of these disorders were comprehensively reviewed through a narrative review of the literature [25]. Concerning $C D$, we have identified more than 130 infections that could be considered "rare diseases" in EU/EEA countries and that are linked to mobility and globalisation (See Table 1).. In addition, many studies also highlight that most of these diseases do not have appropriate and widely available diagnostic techniques and treatments.

Concerning NCD, we have comprehensively reviewed the literature to assess the association between traditional rare diseases (non $\mathrm{CD}$ ) with mobility and globalization in EU/ EEA countries [25]. The online survey was also conducted with experts belonging to the 24 European Reference Networks (ERN) in the EU/EEA to agree the preliminary of rare non-CD identified. Some autosomal recessive disorders have been particularly found to be associated with mobility and globalization, in part because co-sanguinity is more frequent in certain migrant populations.

Other results of the review also showed that most studies were conducted in highly specialized units (particularly in Tropical diseases), suggesting a lack of knowledge among other health professionals regarding imported diseases. It was also concluded that the areas of expertise are quite different between rare NCD and $\mathrm{CD}$. In the particular case of $\mathrm{CD}$, a high expertise is required in some areas of infectious disease, particularly in Tropical Medicine, imported diseases and also tickborne diseases. Due to changes in the epidemiology of rare CD (e.g. West Nile virus or Chikungunya), a network including experts from countries where these diseases are less rare would be helpful to clinicians working in countries where cases are rarely diagnosed. In this regard, although a list of CD has been proposed (See Additional file 1), the list should remain open to be updated in case new diseases are emerging. All these challenges should be considered when designing appropriate strategies to improve the health care provision related to these diseases in people living in EU/EEA countries.

2. A consultation Workshop was conducted on the "Assessment of a European Expert Network on 
Table 1 List of rare communicable diseases linked to mobility and globalisation identified throughout the euradmog study MICROORGANISM related keywords

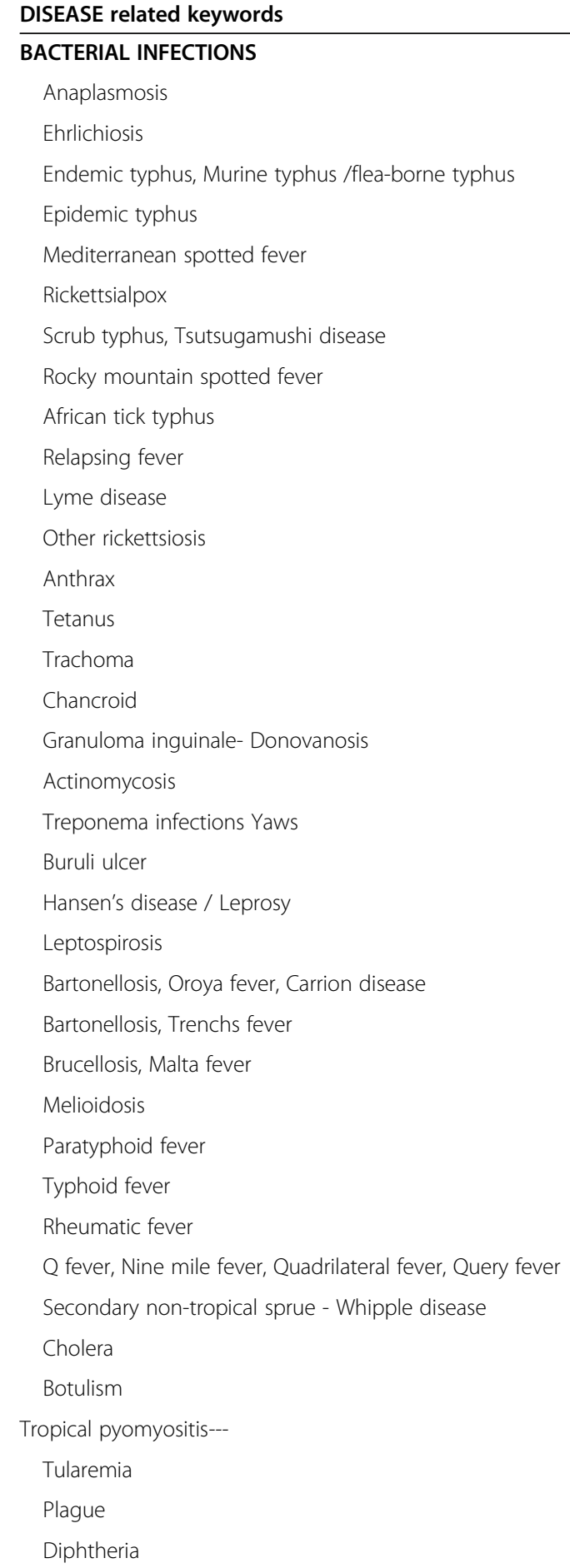

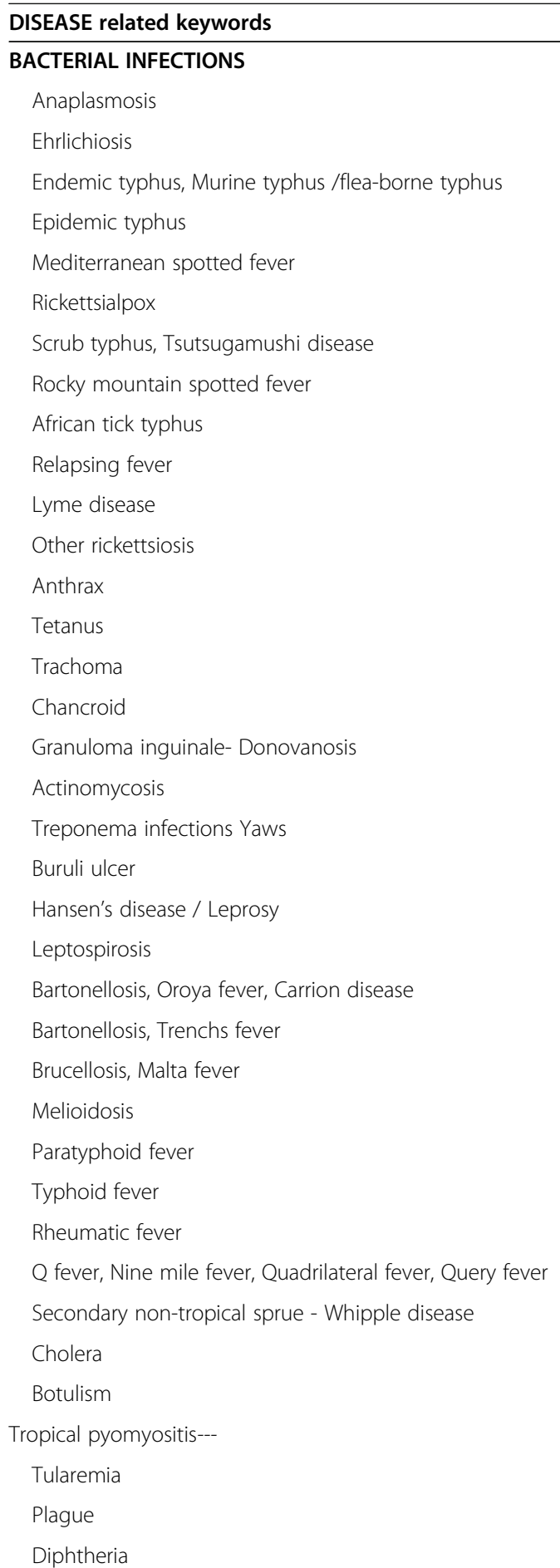

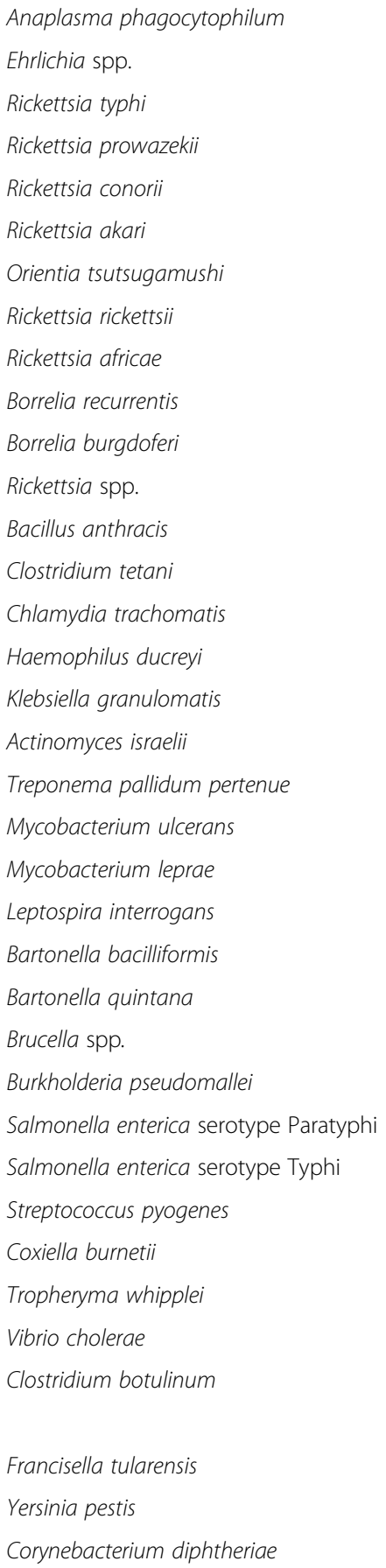

Francisella tularensis

Yersinia pestis

Corynebacterium diphtheriae

\section{FUNGAL INFECTIONS}

Chromomycosis/Chromoblastomycosis

Fonsecaea pedrosoi, Phialophora verrucosa and Cladophialophora carrionii

Madurella mycetomatis

Madura foot /Eumycetoma

Sporothrix schenckii

Sporotrichosis

Paracoccidioides brasiliensis 
Table 1 List of rare communicable diseases linked to mobility and globalisation identified throughout the euradmog study (Continued)

\begin{tabular}{|c|c|}
\hline DISEASE related keywords & MICROORGANISM related keywords \\
\hline Coccidioidomycosis, Desert fever, San Joaquin valley fever, California disease & Coccidioides immitis \\
\hline Peniciliosis & Penicillium marneffei \\
\hline Scedosporiosis & Scedosporium spp. \\
\hline \multicolumn{2}{|l|}{ HELMINTH INFECTIONS } \\
\hline Cystic echinococcosis, Echinococcosis & Echinococcus granulosus \\
\hline Alveolar echinococcosis & Echinococcus multilocularis \\
\hline Ancylostomiasis /Ankylostomiasis & Ancylostoma duodenale /Necator americanus \\
\hline Angiostrongyliasis & Angiostrongylus cantonensis \\
\hline Strongyloidiasis, Anguilluliasis & Strongyloides stercoralis \\
\hline Anisakiasis & Anisakis spp. \\
\hline Ascariasis & Ascaris lumbricoides \\
\hline Bilharziasis, Schistosomiasis & Schistosoma spp. \\
\hline Clonorchiasis & Clonorchis sinensis \\
\hline Opisthorchiasis & Opisthorchis viverrini \\
\hline Cutaneous larva migrans & Ancylostoma spp. \\
\hline Cysticercosis & Taenia solium \\
\hline Diphyllobothriasis & Diphyllobothrium latum \\
\hline Dirofilariasis & Dirofilaria immitis \\
\hline Distomatosis & Other trematodes-Heterophyes heterophyes, Metagonimus spp. \\
\hline Dracunculiasis, Guinea Worm disease & Dracunculus medinensis \\
\hline Fascioliasis & Fasciola spp. \\
\hline Paragonimiasis & Paragonimus spp. \\
\hline Gnathostomiasis & Gnathostoma spp. \\
\hline Hymenolepiasis & Hymenolepsis nana \\
\hline Loiasis & Loa loa \\
\hline Lymphatic filariasis & Wuchereria bancrofti / Brugia malayi \\
\hline Mansonelliasis & Mansonella spp. \\
\hline Onchocerciasis & Onchocerca volvulus \\
\hline Sparganosis & Spirometra spp. \\
\hline Taeniasis & Taenia spp. \\
\hline Trichinosis & Trichinella spiralis \\
\hline Trichuriasis & Trichuris trichiura \\
\hline \multicolumn{2}{|l|}{ PROTOZOAL INFECTIONS } \\
\hline Acanthamoeba infection, Keratitis & Acanthamoeba spp. \\
\hline African trypanosomiasis, Sleeping sickness & Trypanosoma brucei \\
\hline Amebiasis & Entamoeba histolytica \\
\hline Amebic meningoencephalitis & Naegleria fowleri \\
\hline American trypanosomiasis, Chagas disease & Trypanosoma cruzi \\
\hline Babesiosis & Babesia spp. \\
\hline Cryptosporidiosis & Cryptosporidium parvum \\
\hline Cyclosporiasis & Cyclospora cayetanensis \\
\hline Isosporiasis & Isospora belli \\
\hline Leishmaniasis & Leishmania spp. \\
\hline
\end{tabular}


Table 1 List of rare communicable diseases linked to mobility and globalisation identified throughout the euradmog study (Continued)

\begin{tabular}{ll}
\hline DISEASE related keywords & MICROORGANISM related keywords \\
\hline Malaria & Plasmodium spp. \\
Sarcocystosis, Sarcosporidiosis & Sarcocystis hominis
\end{tabular}

\section{VIRAL INFECTIONS}

Avian flu

Brazilian haemorrhagic fever

California encephalitis

Chapare haemorrhagic fever

Chikungunya

Colorado tick-borne disease, Mountain fever, American mountain fever, Mountain tick fever-

Crimea-Congo haemorrhagic fever

Dengue fever

Ebola

Hantavirosis, Haemorrhagic fever-renal syndrome

Hepatitis D

Hepatitis E

Herpes B infection, B virus infection

Tropical spastic paraparesis

Japanese encephalitis

Junin haemorrhagic fever, Argentine haemorrhagic fever

Kyasanur haemorrhagic fever, Kyasanur forest disease, Monkey fever, Monkey disease

La Crosse encephalitis

Lassa haemorrhagic fever

Lujo haemorrhagic fever, Zambian haemorrhagic fever

Machupo haemorrhagic fever

Marburg haemorrhagic fever /Marburg virus disease

Nipah encephalitis, Nipah fever /Nipah virus disease

Omsk haemorrhagic fever

Poliomyelitis, Poliomyelitis in patients with immunodeficiency deemed at risk

Rabies

Rift valley fever

Saint Louis encephalitis

Tick-borne encephalitis

Venezuelan haemorrhagic fever

Western equine encephalitis, Western equine encephalomyelitis

West-Nile encephalitis, West-Nile fever

Yellow fever

Zika virus disease

Middle East respiratory syndrome coronavirus

\section{OTHER CONDITIONS}

Tick paralysis

Cutaneous myiasis

African iron overload
Avian influenza

Sabia virus

California encephalitis virus

Chapare virus

Chikungunya virus

Colorado tick fever (CTF)

CCHF virus

Dengue virus

Ebola virus

Hantavirus

Hepatitis D virus

Hepatitis E virus

Herpesvirus simiae, monkey $B$ virus

Human T-lymphotropic virus 1 (HTLV-1)

Japanese encephalitis virus (JEV)

Junin virus

KFD virus (KFDV)

La Crosse virus (LACV)

Lassa virus

Lujo virus

Machupo virus (MACV)

Marburg virus

Nipah virus

Omsk haemorrhagic fever virus (OHFV)

Poliovirus

Rabies virus

Rift valley fever (RVF) virus

Saint Louis encephalitis (SLE) virus

Tick-borne encephalitis (TBE) virus

Guanarito virus

Western equine encephalitis (WEE) virus

West-Nile virus (WNV)

Yellow fever virus

Zika virus

MERS-COV

Tick

Dermatobia hominis, Cordylobia anthropophaga 
Table 1 List of rare communicable diseases linked to mobility and globalisation identified throughout the euradmog study (Continued)

\begin{tabular}{ll}
\hline DISEASE related keywords & MICROORGANISM related keywords \\
\hline Ciguatera fish poisoning & Tropical pancreatitis \\
Tropical calcific chronic pancreatitis & \\
Tropical pancreatic diabetes & \\
Tropical endomyocardial fibrosis (TEF) & prion disease \\
Acquired Creutzfeldt-Jakob disease & \\
Hyperreactive malarial splenomegaly & \\
Genital female mutilation & \\
Severe fever with thrombocytopenia Syndrome & \\
INFECTIONS wITH PARTICULAR ASPECTS TO BE CONSIDERED & Giardia duodenalis \\
Giardiasis & E.coli (O157) \\
Shiga-like toxin-associated HUS & Mycobacterium tuberculosis \\
Tuberculosis &
\end{tabular}

communicable diseases and other rare pathologies in the context of Mobility and Globalization". Participants of the online survey and belonging to the networks TROPNET, EUROTRAVNET, EVDL ABNET and the existing 24 ERN in the EU/EEA were invited to participate to have a minimum of two health care professionals per country in the EU (the countries participating the study) with expertise on rare diseases linked to mobility and globalisation. Whenever possible, they were selected as one member with expertise in rare-CD (imported or vector-borne diseases) and the other one with expertise in rare NCD. The workshop was finally attended by 57 people (health professionals with expertise in rare $\mathrm{CD}$ and rare NCDs from EU countries, Norway and from the EC) from 26 countries.

In the workshop, besides recognising the growing need to attend rare diseases related to mobility and globalization, the participants almost unanimously agreed to differentiate $\mathrm{CD}$ and NCD. The latter are already covered by different ERNs and should not be included in a new network. Concerning the benefit of a having a network on rare $C D$ with a focus on Health Care provision, several arguments were raised:.

- To find spaces to further enable the discussion of clinical cases; and discussion between clinical and laboratory experts (e.g. in terms of test results, how to deal with false-positives etc.); and also as a meeting point of needs, feedbacks and expertise for Health Care Providers (HCPs) and the external environment (other networks, authorities, health systems, private sectors, etc.). This may reduce inappropriate practice variation.
- To promote the access to complex diagnostic tests and also to drugs for neglected diseases in order to reduce inequalities in health care.

- To give better advice to governments, or to be linking with the European regulatory bodies to improve access to orphan drugs; and to act as a promoter of harmonized strategies and actions (e.g. to improve the standards of screening strategies of imported diseases across Europe for blood or transplant donors, pregnant women or immunosuppressed individuals)

- To supervise and improve online available data and the registry of diseases that are not currently under surveillance, promoting the access to reliable information on new developments.

- To enhance translation of research into practice by reinforcing research and epidemiological surveillance and improve knowledge for physicians, healthcare providers, patients and families.

- To promote clinical evidence-based guidelines on imported diseases based on a robust methodology and exchange of healthcare professionals as well as training and education activities (e.g. webinars, elearning courses or summer schools among others) would be a countless benefit.

- Cross-linking mechanisms with other ERNs should be promoted. Few examples of the types of collaborations in this regard include among others:

(i) To discuss and interact in some diseases that require a multidisciplinary approach (e.g. cysticercosis may require a follow-up from an 
Infectious diseases specialist but also from a Neurologist);

(ii) To discuss with experts belonging to other ERNs the specific problems and requirements of the growing number of travellers to tropical countries who are affected by chronic diseases, e.g. providing specific advice about the drug interaction with malaria chemoprophylaxis or about the contraindications of lived-attenuated vaccine.

3. The feasibility assessment was aimed at analysing how successful a European expert network on rare communicable diseases linked to mobility and globalization focused on Health Care provision would be based on the results of the review and the Consultation Workshop, considering which are the options for building the network.

The options and conditions of creating a European expert network for rare CD linked to Mobility and Globalisation (for diagnosis and treatment) were evaluated, considering three different scenarios:

1) "Status Quo" scenario, where current European networks identified would be enhanced but no new network would be built.

2) To create a specific European expert network (EEN) on rare CD linked to mobility and globalisation with the governance and structure to be defined.

3) To develop a new European Reference Network (ERN) on CD linked to mobility and globalisation in the same way as the current ERNs.

To do the assessment, the operational criteria of a potential network were developed and adapted from the criteria established by the European Commission for ERN (Operational Criteria for the Assessment of Networks) [26]. They were:

1) The establishment, including objectives and activities covered in the network, regulations of the network that should comply with EU regulations, but also the criteria and conditions to constitute the network.

2) The provision of highly specialized care in the areas of diagnosis, treatment and follow-up. This criterion included an assessment of the thematic areas and diseases covered by the network, the capability of improving health care provision and the capacity to create data registries,
3) The governance coordination and management, including the establishment of a board of the network, the coordinator, the criteria that newly formed HCP wishing to join an ERN must meet and the involvement of patients' associations.

4) The ability to promote a good quality and safe patient care by fostering timely and pertinent diagnosis, treatment, follow-up and management across the Network.

5) Continuous education, training and development, including the creation or participation in evidencebased guidelines/recommendations, the sharing of knowledge and technologies and other training activities or education materials.

6) The capacity of conducting and collaborating in research activities (e.g. clinical trials) and the possibility of establishing shared registries and databases aiming to integrate existing resources.

7) The good practice, outcome measures and quality control measures for the network.

8) The multidisciplinary approach.

9) The capacity of establishing further networking and collaborations including the assessment of the added value that the network could bring to health care providers, as well as to other existing networks related to the area of expertise (e.g. other ERNs)

10) The funding sources including a management and business plan.

11) The evaluation of the sustainability considering the minimum of human resources required to maintain the network; possible future funding sources; how to ensure a roster and regular turnover of available experts to work on the network tasks in the future; and how will the information be made available to wider audiences (e.g. establishment of a website, organisation of seminars and conferences).

The detailed information about the results is summarized in Table 2. The main features of each scenario were:

1. "Status Quo" scenario: there are several existing networks with some focus on health care provision and patient care essentially improved through exchange of information, continuous education and training of health professionals. They are TROPNET, EUROTRAVNET and EVDLABNET. However, a proper system -according to EU data protection regulations- has not been implemented to share health data. There are some diseases (particularly endemic vector-borne diseases) not covered by these networks. All current networks are functioning with low financial resources, most of them private, and frequently informal and not 
Table 2 Assessment of the three options for a potential network o rare Communicable diseases linked to Mobility and Globalisation

\begin{tabular}{|c|c|c|c|c|}
\hline & Maintaining Status Quo & $\begin{array}{l}\text { Creation of a European } \\
\text { expert network (EEN) }\end{array}$ & $\begin{array}{l}\text { Creation of a new ERN } \\
\text { (ERN) }\end{array}$ & $\begin{array}{l}\text { Other pending aspects to } \\
\text { be explored }\end{array}$ \\
\hline \multicolumn{5}{|l|}{ Operational criteria } \\
\hline $\begin{array}{l}\text { Establishment of } \\
\text { the network }\end{array}$ & $\begin{array}{l}+ \\
\text { There are three existing } \\
\text { networks. } \\
\text { There are members from non- } \\
\text { EU/EEA countries in the } \\
\text { networks. } \\
\text { They comply the minimum of } \\
\text { HCP and countries required. } \\
\text { The main goal of the } \\
\text { networks is not exclusively } \\
\text { focused on Health care } \\
\text { provision. }\end{array}$ & $\begin{array}{l}+ \\
\text { The EC can set the basis but } \\
\text { there are not currently clear } \\
\text { mechanisms to be supported } \\
\text { by EC (Health policy platform } \\
\text { could be one). } \\
\text { No clear mechanism on who } \\
\text { should establish the expertise } \\
\text { of the HCP. } \\
\text { A minimum of HCP identified } \\
\text { The HCP criteria could be } \\
\text { more flexible compared with } \\
\text { an ERN. } \\
\text { It may partially overlap the } \\
\text { focus of those existing } \\
\text { networks. }\end{array}$ & $\begin{array}{l}+ \text { to }++ \\
\text { The EC and the Member } \\
\text { States set the basis. } \\
\text { The minimum of HCP } \\
\text { identified. } \\
\text { Health Care Provider status } \\
\text { might make difficult the } \\
\text { participation and enrolment } \\
\text { of critical centres. } \\
\text { It may partially overlap the } \\
\text { focus of those existing } \\
\text { networks. }\end{array}$ & $\begin{array}{l}\text { The proposed number of } \\
\text { required number of } \\
\text { participants/ countries needs } \\
\text { to be reviewed and validated }\end{array}$ \\
\hline $\begin{array}{l}\text { Thematic areas } \\
\text { to be covered by } \\
\text { the network: }\end{array}$ & $\begin{array}{l}++ \\
\text { All networks are focused on } \\
\text { Tropical and Travel related } \\
\text { diseases which are rare } \\
\text { communicable diseases linked } \\
\text { to Mobility and Globalisation } \\
\text { (one of them with an } \\
\text { exclusively focus on viral } \\
\text { infections). }\end{array}$ & $\begin{array}{l}++ \\
\text { The network will be created } \\
\text { based on the findings, and } \\
\text { needs in terms of rare CD } \\
\text { linked to Mobility and } \\
\text { Globalisation. }\end{array}$ & $\begin{array}{l}++ \\
\text { The network will be created } \\
\text { based on the findings and } \\
\text { needs in terms of rare CD } \\
\text { linked to Mobility and } \\
\text { Globalisation. }\end{array}$ & \\
\hline $\begin{array}{l}\text { Disease or } \\
\text { conditions } \\
\text { covered }\end{array}$ & $\begin{array}{l}+ \text { to }++ \\
\text { The existing networks already } \\
\text { cover most of the diseases. } \\
\text { In TropNet and EVDLabNet, } \\
\text { there is not a list of diseases. }\end{array}$ & $\begin{array}{l}++ \\
\text { The diseases to be included } \\
\text { can be according to the } \\
\text { detected needs. } \\
\text { The list may not be a closed } \\
\text { list since there are potential } \\
\text { new public health threats for } \\
\text { the EU/EEA countries in the } \\
\text { future. }\end{array}$ & $\begin{array}{l}++ \\
\text { The diseases to be included } \\
\text { can be according to the } \\
\text { detected needs. } \\
\text { The list may not be a closed } \\
\text { list since there are potential } \\
\text { new public health threats for } \\
\text { the EU/EEA countries in the } \\
\text { future. }\end{array}$ & \\
\hline $\begin{array}{l}\text { Improving the } \\
\text { Health Care } \\
\text { Provision }\end{array}$ & $\begin{array}{l}+ \\
\text { TropNet has a forum for } \\
\text { discussion of clinical cases } \\
\text { activity although ensuring the } \\
\text { compliance with the EU data } \\
\text { protection policy is currently a } \\
\text { challenge. } \\
\text { EVDLabNet has a directory of } \\
\text { Laboratory capacities to } \\
\text { improve the access to rare } \\
\text { diagnostics tests. }\end{array}$ & $\begin{array}{l}+ \\
\text { This criterion may be feasible } \\
\text { depending on the legal basis } \\
\text { and cross-exchange mecha- } \\
\text { nisms of the network al- } \\
\text { though ensuring compliance } \\
\text { with the data EU protection } \\
\text { policy may be challenging. }\end{array}$ & $\begin{array}{l}++ \\
\text { This is the main guarantee of } \\
\text { ERN, as well as its main goal, } \\
\text { to ensure a better access to } \\
\text { highly specialized healthcare. }\end{array}$ & \\
\hline Data registry & $\begin{array}{l}\mathbf{0} \text { to }+ \\
\text { TropNet and EuroTravNet do } \\
\text { report number of cases yearly } \\
\text { as a sort of surveillance } \\
\text { activity but do not register } \\
\text { clinical cases. } \\
\text { The existing networks share } \\
\text { data, but cannot be held } \\
\text { responsible nor exchange } \\
\text { personal patient data in a } \\
\text { secure, safe and legally } \\
\text { binding environment in } \\
\text { compliance with the data EU } \\
\text { protection policy, which is } \\
\text { currently a challenge. }\end{array}$ & $\begin{array}{l}+ \\
\text { It is difficult to assess the } \\
\text { feasibility, as it will depend on } \\
\text { the rules, data definition and } \\
\text { legal framework of the } \\
\text { network. } \\
\text { This criterion may be feasible } \\
\text { depending on the legal basis } \\
\text { and cross-exchange mecha- } \\
\text { nisms of the network al- } \\
\text { though ensuring compliance } \\
\text { with the EU data protection } \\
\text { policy may be challenging. }\end{array}$ & $\begin{array}{l}++ \\
\text { This is the main guarantee of } \\
\text { ERN, as well as its main goal, } \\
\text { to ensure a better access to } \\
\text { highly specialized healthcare. } \\
\text { ERNs register clinical cases for } \\
\text { discussion and for a training } \\
\text { purpose (CPMS system). } \\
\text { In addition, another ERNs' } \\
\text { developments include online } \\
\text { platform to safely and } \\
\text { ethically share data, under the } \\
\text { support of the EU in terms of } \\
\text { technological tools enabling } \\
\text { the sharing. }\end{array}$ & \\
\hline $\begin{array}{l}\text { Governance, } \\
\text { coordination } \\
\text { and }\end{array}$ & $\begin{array}{l}\mathbf{0} \text { to }+ \\
\text { Existing networks have } \\
\text { different governance and }\end{array}$ & $\begin{array}{l}+ \\
\text { A new network will mean } \\
\text { new structures and roles, but }\end{array}$ & $\begin{array}{l}++ \\
\text { The governance while } \\
\text { complex is aspect of the ERNs }\end{array}$ & \\
\hline
\end{tabular}


Table 2 Assessment of the three options for a potential network o rare Communicable diseases linked to Mobility and Globalisation (Continued)

\begin{tabular}{llll}
\hline & Maintaining Status Quo & $\begin{array}{l}\text { Creation of a European } \\
\text { expert network (EEN) }\end{array}$ & $\begin{array}{l}\text { Creation of a new ERN } \\
\text { (ERN) }\end{array}$ \\
\hline $\begin{array}{l}\text { management of } \\
\text { the network }\end{array}$ & $\begin{array}{l}\text { coordination structure. } \\
\text { The networks might overlap } \\
\text { in some aspects. It is currently } \\
\text { foreseen to develop more }\end{array}$ & $\begin{array}{l}\text { it does not have to be too } \\
\text { It will depend on the organ } \\
\text { (not necessarily the EC) to }\end{array}$ & $\begin{array}{l}\text { has been already established. } \\
\text { Patient's associations could be }\end{array}$ \\
\hline
\end{tabular}

foreseen to develop more (not necessarily the EC) to collaborations.

Members of the networks may not necessarily be HCP. Patients' associations are not involved in these networks.

Patient care

+ to ++
The networks do not have
guidelines to promote quality
and safe patient care.
Networks also provide
information for patients/
relatives within the network.
EVDLabNet promotes the
sharing of laboratory
capabilities.
TropNet has available a
repository with information
on orphan drugs available in
the centres belonging to the
network.
No network has developed
ICT-tools that could be devel-
oped to provide care, access
to expertise, and support the
development, sharing and
spread of best practice. (E.g.
Telemedicine, tele-expertise or
remote consultation).
Patient care is improved
through continuous exchange
of knowledge.
Few centres from East
European countries are
involved in the networks.

support the network.

Patient's associations could

potentially be involved.

+ to ++

The specialization of the network should enable the creation of formally accepted professionalized guidelines for patient care

The involvement of HCP will depend on the Governance of the network

Discussion of individual clinical cases could be proposed but the maintenance will be a challenge.

ICT tools will depend on available funding.

Most HCPs identified are from Western European countries.

Efforts should be done to include more HCP from East European countries.

Eurean counties.

$++$

The specialization of the network should enable the creation of formally accepted professionalized guidelines for patient care. One of the key function of the ERNs is to standardize care treatment, and the involvement of HCP directly connected to patients will ensure the direct translation of improved treatments. A forum for discussion of individual clinical cases will be proposed.

ICT-tools could be developed to provide care, access to expertise, and support the development, sharing and spread of best practice. (E.g. Telemedicine, tele-expertise or remote consultation).

Most HCPs identified are from Western European countries. Efforts should be done to include more HCP from East European countries. The network complies with the legal framework of the EC in providing Health Care.

\section{Continuous education, training and development.}

$++$

Activities related to continuous education and training are currently being conducted (seminar, scientific meeting, conferences...). They are very close to the professional needs, as facilitated by the exchange and informal atmosphere.

Research activities of the network.

$++$

The health professionals already contribute to research by developing R\&l projects together, including clinical trials, (particularly TropNet).

Good practice, outcome measures and quality control
0 to +

Although the networks promote the exchange of good practices, it is not close to the professionals needs, and targeted to a very specific field. Depending on the resources available, they will be implemented more easily.

The creation of the network itself is part of an R\&l process. The founders will need to decide the relevance of the research for the activities of the network.
These activities would be very

$++$

These activities would very close to the professionals needs, and facilitated by the the official online platforms. Patients' education material are promoted by ERN.

$+\quad++$

Through the formalisation of the network, a set of outcome measures and monitoring exchange of information on
The role and involvement of patients within the network needs to be clarified.
Training and educational activities are limited or not for members of the network.

\section{+ to ++}

The main objective of the ERNs is to improve healthcare services, and the research activities, although secondary, are encouraged through the consortium, and the individuals. Time is a constraint for clinicians involved.

If external funding to fund research is needed.

The amount of time to be dedicated for research by clinicians

ERNs are monitored and controlled by both the HCP and the funder (DG-Sante). A
Define the set of Key Performance Indicators to ensure monitoring and impact driven approach. 
Table 2 Assessment of the three options for a potential network o rare Communicable diseases linked to Mobility and Globalisation (Continued)

\begin{tabular}{|c|c|c|c|c|}
\hline & Maintaining Status Quo & $\begin{array}{l}\text { Creation of a European } \\
\text { expert network (EEN) }\end{array}$ & $\begin{array}{l}\text { Creation of a new ERN } \\
\text { (ERN) }\end{array}$ & $\begin{array}{l}\text { Other pending aspects to } \\
\text { be explored }\end{array}$ \\
\hline $\begin{array}{l}\text { measures for the } \\
\text { network }\end{array}$ & $\begin{array}{l}\text { mandatory to follow up and } \\
\text { monitor the concrete impact } \\
\text { of the exchanges, and the } \\
\text { uptake of new/improved } \\
\text { guidelines. } \\
\text { Cross-border collaborations to } \\
\text { improve the health care } \\
\text { provision have been already } \\
\text { implemented (e.g. EVDLabNet } \\
\text { laboratory capacity sharing or } \\
\text { TROPNET - information access } \\
\text { to Orphan drugs). } \\
\text { There is not a defined quality } \\
\text { control planning with clear } \\
\text { objectives and measurable } \\
\text { indicators for monitoring and } \\
\text { evaluation, particularly } \\
\text { regarding the compliance of } \\
\text { the access to medical records } \\
\text { and clinical information with } \\
\text { the EU regulations. }\end{array}$ & $\begin{array}{l}\text { should be set, and agreed by } \\
\text { the founders, especially to } \\
\text { justify costs and impact, and } \\
\text { obtain funding for their } \\
\text { activities. } \\
\text { However, to assure the } \\
\text { compliance of the access to } \\
\text { medical records and clinical } \\
\text { information with the EU } \\
\text { regulations will be challenge } \\
\text { to create and maintain a } \\
\text { system to assure the } \\
\text { confidentiality. } \\
\text { The network could also create } \\
\text { a standard procedure for } \\
\text { obtaining consent form. }\end{array}$ & $\begin{array}{l}\text { series of Key Performance } \\
\text { Indicators (KPI) have to be } \\
\text { established, and their } \\
\text { outcomes and impact is } \\
\text { measured. } \\
\text { ERN requires a quality control } \\
\text { planning with clear objectives } \\
\text { and measurable indicators for } \\
\text { monitoring and evaluation, } \\
\text { particularly regarding the } \\
\text { compliance of the access to } \\
\text { medical records and clinical } \\
\text { information with the EU } \\
\text { regulations. } \\
\text { The network would also } \\
\text { create a standard procedure } \\
\text { for obtaining consent form. }\end{array}$ & \\
\hline $\begin{array}{l}\text { Multidisciplinary } \\
\text { approach }\end{array}$ & $\begin{array}{l}+ \\
\text { The existing networks have a } \\
\text { very open approach towards } \\
\text { multidisciplinary collaboration, } \\
\text { particularly EuroTravNet. } \\
\text { No clear rules within the } \\
\text { networks on the openness } \\
\text { towards other disciplines is } \\
\text { established. }\end{array}$ & $\begin{array}{l}\text { ? } \\
\text { The founders will need to } \\
\text { decide the relevance given to } \\
\text { multi/trans-disciplinary } \\
\text { approach, within the scheme } \\
\text { decided and the concrete } \\
\text { objectives/goals of the } \\
\text { network. }\end{array}$ & $\begin{array}{l}++ \\
\text { ERN will ensure a } \\
\text { multidisciplinary approach to } \\
\text { treat the diseases/ affectations } \\
\text { at the core of the network. } \\
\text { There is also } 24 \text { other ERNs, } \\
\text { which meet and exchange at } \\
\text { least on a bi-annual basis, } \\
\text { summing up to the concrete } \\
\text { specificities of each one of } \\
\text { them. }\end{array}$ & $\begin{array}{l}\text { Explore how to add social } \\
\text { and gender approach to the } \\
\text { different networks. }\end{array}$ \\
\hline $\begin{array}{l}\text { Networking and } \\
\text { collaboration }\end{array}$ & $\begin{array}{l}\text { + to }++ \\
\text { Networks are already } \\
\text { established, and although } \\
\text { collaboration is well engaged, } \\
\text { both within and towards } \\
\text { other networks, it is necessary } \\
\text { to establish it specifically on } \\
\text { Health Care Provision. } \\
\text { No official collaborations with } \\
\text { other disciplines have been } \\
\text { established (blood banks, } \\
\text { transplant or antenatal care } \\
\text { units among other). }\end{array}$ & $\begin{array}{l}+ \\
\text { Although based on existing } \\
\text { partnership, and related } \\
\text { centres, the general } \\
\text { networking and collaborations } \\
\text { towards external players } \\
\text { would have to be developed. }\end{array}$ & $\begin{array}{l}+ \text { to }++ \\
\text { The general networking and } \\
\text { collaborations towards } \\
\text { external players would have } \\
\text { to be developed. } \\
\text { However, collaboration with } \\
\text { other ERNs may be facilitated } \\
\text { through the ERN structure. }\end{array}$ & $\begin{array}{l}\text { Define better priority lines of } \\
\text { collaboration. }\end{array}$ \\
\hline \multicolumn{5}{|c|}{ Funding and sustainability criteria } \\
\hline Funding sources & $\begin{array}{l}\mathbf{0} \text { to }+ \\
\text { Networks are already } \\
\text { functioning, although with } \\
\text { low or non - financial } \\
\text { resources. } \\
\text { EVDLabNet is funded by the } \\
\text { ECDC. } \\
\text { Private funding sources: } \\
\text { EuroTravNet is currently } \\
\text { funded by private institutions } \\
\text { (International Society of Travel } \\
\text { Medicine and the Instituts } \\
\text { Hospitalo-Universitaire Médi- } \\
\text { terranée Infection Foundation, } \\
\text { Marseille). } \\
\text { TROPNET is not funded. }\end{array}$ & $\begin{array}{l}\text { ? } \\
\text { Important funding is needed } \\
\text { to create a network. } \\
\text { The feasibility is very much } \\
\text { depending if a special } \\
\text { funding line is put in place to } \\
\text { support the new structure or } \\
\text { if the sources have to be } \\
\text { identified and obtained } \\
\text { through standard competitive } \\
\text { processes. }\end{array}$ & $\begin{array}{l}++ \\
\text { To start the activities, an ERN } \\
\text { could receive resources from } \\
\text { EU Health programme. } \\
\text { A call for a new ERN would } \\
\text { provide the necessary funding } \\
\text { to start the activity. }\end{array}$ & $\begin{array}{l}\text { Funding sources need to be } \\
\text { available in order to start } \\
\text { new activities, or consolidate } \\
\text { those already existing. }\end{array}$ \\
\hline Sustainability & 0 to + & $?$ & + to ++ & Define the basis of self- \\
\hline
\end{tabular}


Table 2 Assessment of the three options for a potential network o rare Communicable diseases linked to Mobility and Globalisation (Continued)

\begin{tabular}{|c|c|c|c|c|}
\hline & Maintaining Status Quo & $\begin{array}{l}\text { Creation of a European } \\
\text { expert network (EEN) }\end{array}$ & $\begin{array}{l}\text { Creation of a new ERN } \\
\text { (ERN) }\end{array}$ & $\begin{array}{l}\text { Other pending aspects to } \\
\text { be explored }\end{array}$ \\
\hline $\begin{array}{l}\text { analysis of the } \\
\text { network }\end{array}$ & $\begin{array}{l}\text { For now, networks have been } \\
\text { sustainable, as shown on their } \\
\text { existence overtime, and some } \\
\text { key collaborations or merger } \\
\text { are sought for. } \\
\text { It is unclear though how } \\
\text { sustainability is foreseen over } \\
\text { time if networks wish to grow } \\
\text { and to strengthen the } \\
\text { activities focused on Health } \\
\text { Care Provision. }\end{array}$ & $\begin{array}{l}\text { To ensure sustainability } \\
\text { should be part of the basis of } \\
\text { the new network. If there is a } \\
\text { possibility to get the funds, a } \\
\text { sustainability strategy should } \\
\text { be put in place, through the } \\
\text { engagement of the partners. }\end{array}$ & $\begin{array}{l}\text { Sustainability is a key aspect } \\
\text { of the ERNs, although for } \\
\text { now, the experience is too } \\
\text { recent to have a concrete } \\
\text { model (publicly funded, } \\
\text { through European or National } \\
\text { schemes) that can be } \\
\text { replicated for this new ERN. } \\
\text { It is unclear yet how they will } \\
\text { become self-sustainable } \\
\text { overtime. }\end{array}$ & $\begin{array}{l}\text { sustained network, ensure } \\
\text { sustainability through mul- } \\
\text { tiple funders, but also } \\
\text { through clear and set en- } \\
\text { gagement of the stakeholders } \\
\text { involved. }\end{array}$ \\
\hline
\end{tabular}

Full note: In the assessment of each scenario, each criterion was rated once for the overall network. Each criterion has been graded in the following way: "0" The scenario proposed does not fulfil the criterion; " + " The scenario proposed fulfil the criterion with limitations; " ++ " The scenario proposed fulfils the criterion; "?" Difficult to assess, (for the variables and knowledge limitations on the aspects assessed)

necessarily recognised by the national health care systems.

2. A EEN would have the benefit of being created based on the findings and detected needs. Focus would be Health Care provision, and areas and diseases to be included would be the ones identified as rare diseases linked to mobility and globalisation. However, implementing a good system for data registry or discussion of clinical cases would be challenging in terms of sustainability. In addition, there is not a clear mechanism to guarantee the establishment of the EEN supported by the EC, and also the general networking and collaborations with external players would have to be developed. Finally, funding is needed and sources have to be identified, also in order to sustain the network, particularly if a special funding line is not put in place to support the new structure.

3. The basis and the legal status for an ERN have already been established. Governance is a complex aspect for ERNs [26]. Health Care Provision and specialized care status is decided by national health authorities and the participation and enrolment of centres are decided at national level [5]. The areas and diseases covered would be based on the detected needs. The current ERNs are supported with technological tools and online platforms facilitating the safe and ethically acceptable exchange of data, including the registries of cases. A call for a new ERN would provide the necessary funding to start the activity. Sustainability is a key aspect of the ERNs, although the experience is too recent to have a thorough model.

\section{Discussion}

Providing highly specialised diagnosis, treatment and care for patients who have complex diseases can be a challenge [27]. This is especially true when the prevalence of such diseases is low, or when a new disease is emerging as is the case for rare diseases linked to mobility and globalisation. This challenge is due both to the scarcity of expertise and to the scattering of small patient populations across the EU, sometimes in isolated locations where expertise does not exist or cannot be accessed. As a way of example, the evolution of the COVID-19 pandemic is affecting the European Member States (EU MS) with different levels of severity and with an epidemiological situation is evolving very quickly [28]. Although it is not a rare disease anymore in Europe, and the level of knowledge is similar in all EU countries, it is a novel emerging disease unknown for most health professionals and to establish a proper system for sharing information and to establish potential collaborations across countries would be highly valuable.

Many patients are in the need of highly specialised care in third level hospitals. The practical experience on how to manage the patients and in particular the severe cases is scarce and scattered in Europe [27]. While the experience and the number of cases treated by some Hospitals (and MS) is important, due the accumulated expertise, other are still starting to deal with complex patients. Following the previous example, the treatments applied to the COVID-19 patients are in many cases experimental and there are some limitations to reach the knowledge generated during the last months and weeks. Therefore, a new ERN could help to integrate the expertise and competence of those that have already have them with the healthcare professionals that are directly in charge of the patients by facilitating a quick exchange of knowledge and experiences and assisting in the decision making process and ultimately to benefit the patients suffering the condition [27].

A European network on rare CD linked to mobility and globalisation may provide a unique opportunity for clinicians to work across borders in EU/EEA countries in healthcare provision in order to tackle this challenge. 
Coordination strategies among EU/EEA countries to fight against new emerging communicable diseases may be facilitated if there is a network oriented to improve the diagnosis capacity and treatment options for patient and learning from health professional experiences from EU/EEA countries where the diseases have progressed first. The network could also be well aligned with other European initiatives or programmes in place on communicable diseases such as the ECDC associated networks, or the One Health European Joint Programme without overlapping or eclipsing any function or role of such programmes or initiatives.

On the other hand, the study has several limitations that need to be recognized. First, the heterogeneity of the access to health care provision for individuals at risk of mobility associated infectious diseases across EU countries has not been properly evaluated. This is of particular importance for undocumented migrants who have restrictive access to health care services. This element needs to be considered and evaluated when the network is implemented. Second, the connection with other initiatives or programmes with common objectives at national and also at EU level need to be better evaluated to be complementary instead of overlapping activities. Finally, the sustainability of is a key aspect as per the rest of ERN that need a widespread assessment although for now, the experience of ERNs is too recent to have a concrete model.

\section{Conclusions}

If the focus is the health care provision, it could be concluded that an ERN could have the potential to better boost the quality of care. However, current existing networks should not be eclipsed by a potential new network and they should be complementary. Future steps should explore the Member states view and discussion on the appropriateness for launching a new ERN.

\section{Supplementary information}

Supplementary information accompanies this paper at https://doi.org/10. 1186/s13023-020-01534-1.

\section{Additional file 1.}

\section{Abbreviations}

EU: European Union; EEA: European Economic Area; ERN: European Reference Network; EC: European Commission; CD: Communicable diseases; NCD: Non communicable diseases; SCD: Sickle cell disease; HCP: Health Care Providers

\section{Acknowledgements}

We acknowledge all the participants in the consultation workshop that have contributed with their ideas to the feasibility report and also the representatives from the European Commission that have supported this projects.

The study does not involve and animals, humans or human data, human tissue or plants.
The manuscript does not contain personal data in any form.

\section{Authors' contributions}

ARM coordinated the review, participated in the workshop and coordinated the feasibility study, and wrote the manuscript; ZB participated in the workshop and collaborated in the feasibility study and reviewed the manuscript; JLVC participated in the review, in the workshop and reviewed the manuscript, JG coordinated the workshop, collaborated with the feasibility study and reviewed the manuscript; AP coordinated the EURaDMoG project, supervised the workshop and the feasibility study and supervised the manuscript. All authors read and approved the final manuscript.

\section{Funding}

This work has been fully financed by the European Commission (Service Contract 20177110). Open access funding provided by Karolinska Institute.

Availability of data and materials

Supporting data will be available through request to the EC who are the owners of the data.

Ethics approval and consent to participate

This study does not require an ethical approval or consent to participate.

\section{Consent for publication}

All authors have given consent for publication.

\section{Competing interests}

No competing interest.

\section{Author details}

${ }^{1}$ Barcelona Institute for Global Health (Hospital Clínic- Universitat de Barcelona), Barcelona, Spain. ${ }^{2}$ Department of Medicine, Karolinska Institutet, Solna, 17176 Stockholm, Sweden. ${ }^{3}$ Department of Infectious - Tropical Diseases and Microbiology, IRCCS Sacro Cuore Don Calabria Hospital, Negrar (Verona) Italy. ${ }^{4}$ Department of Diagnostics and Public Health, University of Verona, Verona, Italy. ${ }^{5}$ Institute for Leukaemia Research Josep Carreras (IJC), Badalona (Barcelona), Spain.

Received: 16 December 2019 Accepted: 7 September 2020

Published online: 16 October 2020

\section{References}

1. Gushulak B, Weekers J, Macpherson D. Migrants and emerging public health issues in a globalized world: threats, risks and challenges, an evidencebased framework. Emerg Health Threats J. 2009;2:e10.

2. European Centre for Disease Prevention and Control. Migrant health: Background note to the 'ECDC Report on migration and infectious diseases in the EU': ECDC; 2009.

3. European Commission. Rare diseases from: https://ec.europa.eu/health/rare_ diseases/policy_en. Accessed 22 Sept 2020.

4. European Commission. Communication from the commission to the European Parliament, the council, the European economic and social committee and the committee of the regions. On rare diseases: Europe's challenge. 2008. From: https://op.europa.eu/en/publication-detail/-/ publication/c8a042d8-ffb9-4b01-9c91-c1497a2b3fd7/language-en.

5. Héon-Klin V. European reference networks for rare diseases: what is the conceptual framework? Orphanet J Rare Dis. 2017;12:137.

6. Hartman AL, Hechtelt Jonker A, Parisi MA, Julkowska D, Lockhart N, Isasi R. Ethical, legal, and social issues (ELSI) in rare diseases: a landscape analysis from funders. Eur J Hum Genet 2019. 2020;28(2):174-81.

7. Perez-Molina JA, Lopez-Polin A, Trevino B, Molina I, Goikoetxea J, DiazMenendez $M$, et al. 6-year review of +Redivi: a prospective registry of imported infectious diseases in Spain. J Travel Med. 2017;24(5).

8. Abubakar I, Aldridge RW, Devakumar D, Orcutt M, Burns R, Barreto ML, et al. The UCL-Lancet Commission on migration and health: the health of a world on the move. Lancet. 2018;392(10164):2606-54.

9. Lindenmeyer A, Redwood S, Griffith L, Teladia Z, Phillimore J. Experiences of primary care professionals providing healthcare to recently arrived migrants: a qualitative study. BMJ Open. 2016;6(9):e012561. 
10. European Centre for Disease Prevention and Control. Assessing the burden of key infectious diseases affecting migrant populations in the EU/EEA: ECDC; 2014. Contract No.: TQ-04-14-474-EN-N.

11. Bruckner GK. Ensuring safe international trade: how are the roles and responsibilities evolving and what will the situation be in ten years' time? Rev Sci Tech. 2011;30(1):317-24.

12. Medlock JM, Hansford KM, Versteirt V, Cull B, Kampen H, Fontenille D, et al. An entomological review of invasive mosquitoes in Europe. Bull Entomol Res. 2015;105(6):637-63.

13. Medlock JM, Leach SA. Effect of climate change on vector-borne disease risk in the UK. Lancet Infect Dis. 2015;15(6):721-30.

14. Le Tyrant M, Bley D, Leport C, Alfandari S, Guegan JF. Low to medium-low risk perception for dengue, chikungunya and Zika outbreaks by infectious diseases physicians in France, Western Europe. BMC Public Health. 2019; 19(1):1014.

15. Mathis M, Briand S. Climate change, epidemics and the importance of travel and tropical medicine. Rev Med Suisse. 2019;15(649):898-900.

16. Mancuso JD, Garges EC, Hickey PW, Coldren RL, Korman AK, Keep LW, et al. Outcomes from U.S. military-supported overseas training rotations in tropical medicine and Global Health, 2006-2015. Mil Med. 2017;182(9): e1796-e801.

17. Hoffmann T, Straus S. Sharing knowledge for health care. JAMA Intern Med. 2017;177(9):1243-4.

18. Zur B. Increase in genetically determined anemia as a result of migration in Germany. Internist (Berl). 2016;57(5):444-51.

19. Gelpi AP. Migrant populations and the diffusion of the sickle-cell gene. Ann Intern Med. 1973;79(2):258-64.

20. European Commission. European Reference Networks: European Commission; 2019. Available from: https://ec.europa.eu/health/ern_en.

21. Orphanet list of rare diseases. https://www.orpha.net/consor/cgi-bin/ Disease_Search_List.php?Ing=EN. Accessed 20 Mar 2020.

22. European Network for Tropical Medicine and Travel Health - TROPNET. http://tropnet.eu/. Accessed 21 Mar 2020

23. The European Travel and Tropical Medicine Network of the Internatinal Society of Travel Medicine (EuroTravNet). https://www.istm.org/eurotravnet. Accessed 21 Mar 2020.

24. The European Expert laboratory network for emerging viral diseases (EVDLabNet). https:/www.evd-labnet.eu/. Accessed 21 Mar 2020.

25. Prospero Registry - Rare communicable diseases in Europe linked to mobility and globalization: a protocol for a systematic review and metaanalysis of disease frequencies. https://www.crd.york.ac.uk/prospero/display_ record.php?RecordID=126549. Accessed 22 Sept 2020.

26. Heon-Klin V. European reference networks for rare diseases: what is the conceptual framework? Orphanet J Rare Dis. 2017;12(1):137.

27. Wijnen R, Anzelewicz SM, Petersen C, Czauderna P. European reference networks: share, care, and cure-future or dream? Eur J Pediatr Surg. 2017; 27(5):388-94.

28. Bade LR, Rubin EJ. Covid-19. The search for effective therapy. N Engl J Med. 2020;382(19):1851-2.

\section{Publisher's Note}

Springer Nature remains neutral with regard to jurisdictional claims in published maps and institutional affiliations.

Ready to submit your research? Choose BMC and benefit from:

- fast, convenient online submission

- thorough peer review by experienced researchers in your field

- rapid publication on acceptance

- support for research data, including large and complex data types

- gold Open Access which fosters wider collaboration and increased citations

- maximum visibility for your research: over $100 \mathrm{M}$ website views per year

At BMC, research is always in progress.

Learn more biomedcentral.com/submissions 